\title{
Deciphering the self-perceived dilemma of oral health among university students
}

\author{
Shahida Maqsood, Bushra Jabeen, Sanam Faheem, Maqsood Ahmed Soomro and Muznah Sultan \\ Dow University of health Sciences, Karachi, Pakistan
}

\begin{abstract}
Objective: The aim of this study is to assess self-reported oral health knowledge and practices among academicians of province of Sindh, Pakistan

Methodology: A descriptive cross-sectional study was conducted with the help of a self-administered questionnaire, among students from all academic years of different colleges in province of Sindh, Pakistan. Sample size was calculated to be 647 . The questionnaire inquired about demographic details of students which included students' age, gender and specialty. First part of questionnaire assessed knowledge of the students about their oral health care while the second part was based on practices. Results were defined using descriptive statistics.
\end{abstract}

Results: Results showed that students from all three departments participated equally in the study, while females were seen to be in majority among the sample. A huge number of respondents went to visit dentists only when needed. Tooth brush with tooth paste was found to be the commonest method of teeth cleaning. Most of the respondents believed that smoking has harmful effects on teeth and oral conditions cannot be isolated from systemic problems. Once daily brushing was reported among most of the students with frequent sugary food intake and habit of having snacks between meals. Major reason for delaying dental visit was cost factor.

Conclusion: Despite proximal access of dental services, most of the students did not have the habit of visiting dental clinic timely and lacked sufficient awareness about oral health care. It is therefore recommended that comprehensive awareness sessions be conducted for students.

\section{Introduction}

Oral wellbeing is a straightforward and essential piece of undergrads' lives yet may regularly be ignored or undermined as a result of expanded feelings of anxiety and unfortunate propensities related with the school setting. Although quite difficult, school days might be a standout amongst other circumstances to build up long lasting solid habits, including oral wellbeing schedules [1]. Well maintained dental wellbeing not only elevates a person to look and feel good, it additionally helps in saving oral activities. Oral wellbeing is viewed as a vital piece of a person's general wellbeing [2].

The proceeding increment in the predominance of dental caries and periodontal infections in the developing nations makes it necessary to present essential oral health care in the educational modules of public wellbeing courses. The securing of proper information and identifying with oral wellbeing, oral maladies, anticipation and administration of dental issues is imperative $[3,4,5]$.

As undergraduates and post graduates change from pre-adulthood into adults, their wellbeing propensities may influence their future health inclinations. Amid this progress, the individuals who have poor oral hygiene may acquire better habits in the event that they are given good counsel. Accordingly, it is fundamental and vital to look at students' wellbeing practices on the basis that these practices affect students' physical wellbeing and ways of life as they grow [6]. Studies have found that undergrads with better self-assessed wellbeing status or those studying in health sciences related fields are occupied with healthier practices and had more positive wellbeing related demeanors and propensities than different students had. For instance, medicinal school students hold fast to a more positive, healthy ways of life than non-health related students [7].
The association between awareness and behaviourhas been discussed earlier too [8]: knowledge, behaviour, cognition and capabilities are predispositions to act. And this relation happens to be much significant in professionally qualified people when compared to general people $[9,10]$.

Oral self-care practice is a successful preventive measure for keeping up great individual oral wellbeing which is a necessary piece of one's general wellbeing. For dental wellbeing experts, their health convictions and states of mind influence their oral self-care measures as well as conceivably impact their capacity to persuade patients to embrace preventive oral health care methods $[11,12]$. This thus affects peoples comprehension of preventive oral wellbeing measures [9]. It is in perspective of this vital connection that Kawamura et al [13], pushed for undergrad dental training to incorporate extensive projects in preventive care that enables dental practitioners to propel patients for oral self-care. Such instructive exertion should empower dental understudies create stable wellbeing practices [12] which are not impacts by individuals' qualities [10,14].

Aim of current investigation is to get to self-revealed oral wellbeing practices, demeanors and way of life among Students of Sindh, Pakistan

Correspondence to: Muznah Khalid, Dow University of Health Sciences, Karachi, Pakistan. E-mail: muznah.khalid@duhs.edu.pk

Key words: Oral health, knowledge, practices, University students

Received: July 24, 2017; Accepted: July 27, 2017; Published: July 31, 2017 


\section{Program wise distribution of sample}

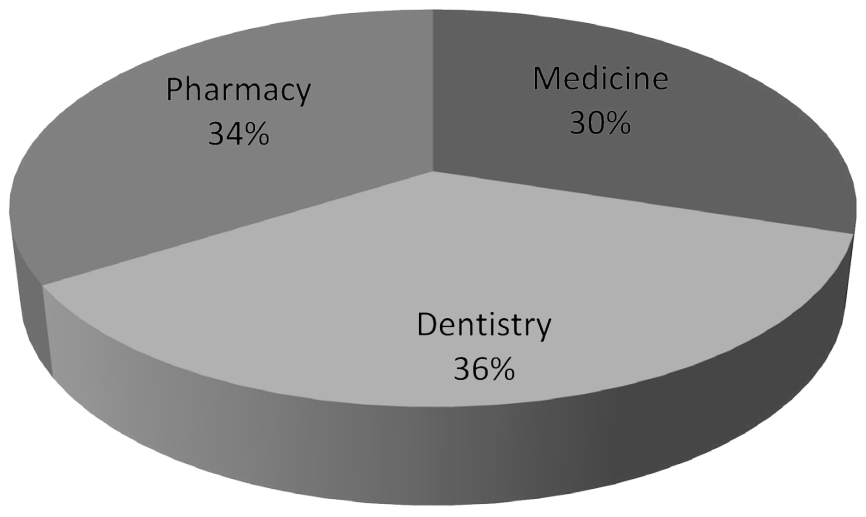

Figure 1. Program wise distribution of sample

\section{Gender wise distribution of sample}

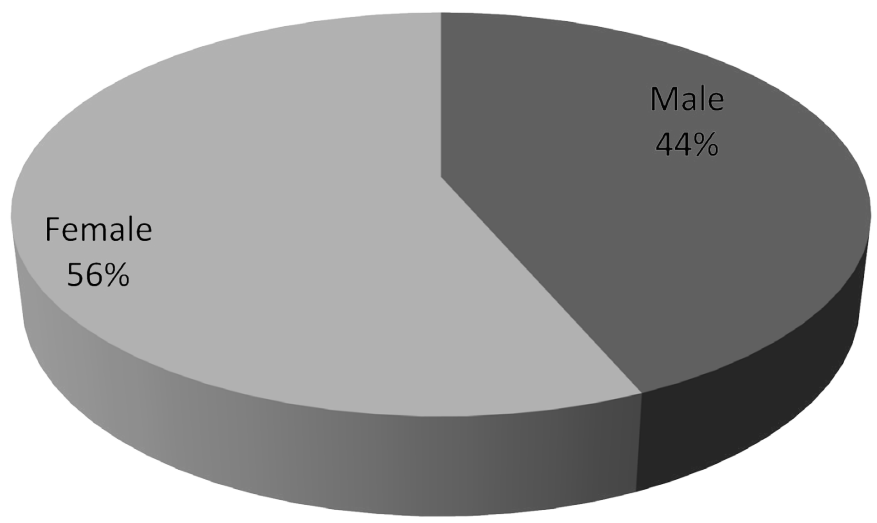

Figure 2. Gender wise distribution of sample

\section{Objectives}

To assess oral hygiene practices, problems, awareness and habits among students of Sindh colleges, Pakistan.

\section{Methodology}

Data was collected in person and also via online form distributes among students undergoing graduates and postgraduate studies in different colleges of province of Sindh, Pakistan. It is a cross sectional descriptive study. Sample size was 647. Among them number of respondents who were as students undergoing severe stress or depression and absent at the time of survey were excluded, as depression can lead to false positive reporting of results. Consent was taken prior to filling of questionnaire from all students. Data from these students was collected using a structured self-administered questionnaire. The questionnaire comprised of demographic details as age, gender and specialty of the student, however anonymity was assured by not recording the name of the respondents. First part of the questionnaire comprised of questions about knowledge related to oral health which included dental visits information, usage of several cleaning equipment and methods, and effects of smoking and dietary habits. Second part of the questionnaire comprised of behavior and practices about oral health care. The questions included were about frequencies of meals and brushing. Also questions regarding delaying dental visits were included.

\section{Results}

Among reasons for visiting the dentist, dental pain or emergency was the most reported reason according to students (69.40\%). Esthetics was the second main reason $(22.72 \%)$. Reasons for delaying the visit cost $(39.88 \%)$, time shortage $(27.67 \%)$ and fear of dental procedures (20.40\%). Frequency of teeth brushing only once daily was found among majority of students (41.58\%). Most of the students (72.49\%) believed that smoking is the causative of agent of oral cancer and majority $(70.02 \%)$ believed that oral health and general health is interrelated.

\section{Discussion}

Patients must be well informed regarding correct practices and increase awareness of oral diseases by their health care providers. The fact that these students are future health care takers of nation, they must inherit proper oral health care measures, behavior and attitude during their study course, so they can guide patients in a proper manner. In Pakistan students are exposed to patients in their third years during their clinical and hospital rotations. Although studies had been conducted in different parts of the globe accessing oral hygiene perception among students $[13,14,15]$. In Pakistan very few studies have given serious consideration in this regard.

The results demonstrated majority of the students had concern regarding their oral health status. This is in line with study conducted among Turkish students. Previous researches have also depicted that dental hygiene practices are defined by gender and female members

Table 1. Knowledge about oral health

\begin{tabular}{|c|c|c|}
\hline & & $\mathrm{N}=647$ \\
\hline \multirow[t]{3}{*}{$\begin{array}{l}\text { Appropriate age for first } \\
\text { dental visit }\end{array}$} & during first year of life & $142(21.95 \%)$ \\
\hline & $\begin{array}{l}\text { after eruption of all primary } \\
\text { teeth }\end{array}$ & $52(08.03 \%)$ \\
\hline & unless needed & $453(70.02 \%)$ \\
\hline \multirow[t]{6}{*}{ Best teeth cleaning aid } & tooth brush only & $12(01.85 \%)$ \\
\hline & tooth paste with finger & $3(00.46 \%)$ \\
\hline & tooth brush with tooth paste & $255(39.41 \%)$ \\
\hline & dental floss & $35(05.41 \%)$ \\
\hline & chlorehexidine mouthwash & $102(15.77 \%)$ \\
\hline & brushing and flossing & $240(37.09 \%)$ \\
\hline \multirow[t]{2}{*}{$\begin{array}{l}\text { Is flouride beneficial for } \\
\text { teeth }\end{array}$} & yes & $387(59.81 \%)$ \\
\hline & no & $260(40.19 \%)$ \\
\hline \multirow[t]{4}{*}{$\begin{array}{l}\text { Tooth paste is chosen } \\
\text { because of }\end{array}$} & flavour & $116(17.93 \%)$ \\
\hline & price & $110(17.00 \%)$ \\
\hline & effectiveness & $158(24.42 \%)$ \\
\hline & brand & $263(40.65 \%)$ \\
\hline \multirow[t]{4}{*}{ Knowledge about diet } & sugar is harmful for teeth & $139(21.48 \%)$ \\
\hline & fresh fruits are good for teeth & $189(29.21 \%)$ \\
\hline & $\begin{array}{l}\text { flavoured juices are good } \\
\text { for teeth }\end{array}$ & $56(08.66 \%)$ \\
\hline & soft drinks are erosive & $263(40.65 \%)$ \\
\hline \multirow{3}{*}{$\begin{array}{l}\text { Smoking habit and its effect } \\
\text { on health }\end{array}$} & smoking causes oral cancer & $496(72.49 \%)$ \\
\hline & $\begin{array}{l}\text { smoking causes staining } \\
\text { of teeth }\end{array}$ & $138(21.33 \%)$ \\
\hline & $\begin{array}{l}\text { smoking has no effect on } \\
\text { teeth }\end{array}$ & $13(02.01 \%)$ \\
\hline \multirow{2}{*}{$\begin{array}{l}\text { Influence of oral health upon } \\
\text { general health }\end{array}$} & oral health has an impact & $453(70.02 \%)$ \\
\hline & oral health has no impact & $194(29.98 \%)$ \\
\hline
\end{tabular}


Table 2. Oral health Practices

\begin{tabular}{|l|l|l|}
\hline Oral health Practices & & \\
\hline & & $\mathrm{N}=647$ \\
\hline Frequency of tooth brushing & once daily & $269(41.58 \%)$ \\
\hline & twice daily & $122(18.86 \%)$ \\
\hline & once weekly & $119(18.39 \%)$ \\
\hline & do not brush regularly & $137(21.17 \%)$ \\
\hline Frequency of sugar intake & once daily & $263(40.65 \%)$ \\
\hline & more than once daily & $250(38.64 \%)$ \\
\hline & once or twice weekly & $97(14.99 \%)$ \\
\hline Last dental visit & do not take sugars & $37(05.72 \%)$ \\
\hline & last month & $67(10.36 \%)$ \\
\hline & last year & $287(44.36 \%)$ \\
\hline & more than a year ago & $164(25.35 \%)$ \\
\hline $\begin{array}{l}\text { Reason for visiting the } \\
\text { dentist }\end{array}$ & don't remember & $129(19.94 \%)$ \\
\hline & dental pain & $449(69.40 \%)$ \\
\hline & esthetics & $147(22.72 \%)$ \\
\hline $\begin{array}{l}\text { Reason for delaying dental } \\
\text { visit }\end{array}$ & routine check up & $51(07.88 \%)$ \\
\hline & fear & $132(20.40 \%)$ \\
\hline & cost & $258(39.88 \%)$ \\
\hline Frequency of meals per day & two & $78(12.06 \%)$ \\
\hline & three & $179(27.67 \%)$ \\
\hline & $\begin{array}{l}\text { more than three with snack } \\
\text { between meals }\end{array}$ & $456(70.48 \%)$ \\
\hline & & $38(05.87 \%)$ \\
\hline
\end{tabular}

of the society have shown to be in a position of better maintaining their dental health $[16,17]$. The fact that in Pakistan, ratio of Females in medical school is much high than males can be one of the reasons, for this increased concern regarding their aesthetics. This increased concern is also found in a similar study [19].

The oral hygiene habits of this sample were different from previous studies as $41.58 \%$ reported only once daily brushing and alarmingly $21.17 \%$ said that they do not brush regularly. Tooth brushing and flossing habits have been studied previously too, wherein it has been reported that most of the respondents brush twice daily or more, however, the usage of dental floss continues to stay low [20,21, 22, 23]. Just like a study conducted in Turkey showed that $67.6 \%$ and another one conducted in Italy showed that $92.1 \%$ of university students had a habit of brushing their teeth twice or even more daily, although dental flossing was only seen in $14.9 \%$ of Italian students and $3 \%$ of Turkish students $[24,23]$.

A study by Baseer MA et al reported concern among dental students regarding their oral hygiene, overall these reported students had poor oral health awareness which was contrary to our findings where Students were well aware of their dental hygiene. This can be a clear indication of increase awareness programs among dental students in Pakistan regarding Oral Hygiene than in students of Middle East.

The relatively frequent use of sugary foods intake by students may be because of their dependence and easy access to dental facility when need be. Although this aspect has to be investigated even more. Studies done in past have shown that instead of free and easy availability of dental care, dental visits were not seen among a large number of students $[25,26,27]$. A study in Jordan showed that $80 \%$ of the sample visited their dentists only for emergency treatments [24].

Overall, the habits of university students towards maintaining their oral hygiene was much lower than should have been among health sciences students. Programmed dental health education sessions may be incorporated in all specialties of health sciences to promote good dental hygiene maintenance [24].

\section{Conclusion}

Confounding factors in present study was unequal ratio of gender due to increase female students, perception of students from different socioeconomic backgrounds have variations in their course fees and cultural differences. Further studies taking into consideration these factors and on a larger scale can reveal more interesting findings.

\section{References}

1. Crabtree R, Kirk A, Moore M, Abraham S (2016) Oral Health Behaviors and Perceptions Among College Students. Health Care Manag (Frederick) 35: 350-360. [Crossref]

2. Jaber MF, Khan A, Elmosaad Y, Mustafa MM, Suliman N, et al. (2017) Oral health knowledge, attitude and practices among male Qassim university students. Int $J$ Community Med Public Health. 4:2729-35.

3. Mynors-Wallis J, Davis DM (2004) An assessment of the oral health knowledge and recall after a dental talk amongst nurses working with elderly patients: a pilot study. Gerodontology. 21:201-4. [Crossref]

4. Frenkel H, Harvey I, Needs K (2002) Oral health care education and its effect on caregivers' knowledge and attitudes: a randomised controlled trial. Community Dent Oral Epidemiol. 30:91-100. [Crossref]

5. Croghan E, Johnson C, Aveyard P (2004) School nurses: policies, working practices, roles and value perceptions. J Adv Nurs. 47:377-85. [Crossref]

6. Liou MY, Lu CM (2006) Related factors of health behavior in university students Chinese J School Health. 48:19-37.

7. Huang YH, Chiou CJ (1997) Predictors contributing to health-promoting lifestyles among college students in Kaohsiung area. Chinese J Public Health. 16:24-36.

8. Brown G, Manogue M, Rohlin M (2002) Assessing attitudes in dental education: is it worthwhile? Br Dent J 193: 703-707. [Crossref]

9. Cortes FJ, Nevot C, Ramon JM, Cuenca E (2002) The evolution of dental health in dental students at the University of Barcelona. J Dent Educ. 66:1203-8. [Crossref]

10. Folayan MO, Khami MR, Folaranmi N, Popoola BO, Sofola OO, et al. (2013) Determinants of preventive oral health behaviour among senior dental students in Nigeria. BMC oral health. 13:28. [Crossref]

11. Ghasemi H, Murtomaa H, Vehkalahti MM, Torabzadeh H (2007) Determinants of oral health behaviour among Iranian dentists. Int Dent J 57:237-242. [Crossref]

12. Freeman R (1999) The psychology of dental patient care. 5. The determinants of dental health attitudes and behaviours. Br Dent $J$ 187: 15-18. [Crossref]

13. Kawamura M, Yip HK, Hu Y, Komabayashi T (2001) A cross-cultural comparison of dental health attitudes and behaviour among freshman dental students in Japan, Hong Kong and West China. Int Dent J. 51:159-63. [Crossref]

14. Polychronopoulou A, Kawamura M, Athanasouli T (2002) Oral self-care behavior among dental school students in Greece. J Oral Sci 44: 73-78. [Crossref]

15. Dagli RJ, Tadakamadla S, Dhanni C, Duraiswamy P, Kulkarni S (2008) Self reported dental health attitude and behavior of dental students in India. J Oral Sci 50: 267-272. [Crossref]

16. Kassak KM, Dagher R, Doughan B (2001) Oral hygiene and lifestyle correlates among new undergraduate university students in Lebanon. $J$ Am Coll Health. 50:15-20. [Crossref]

17. Tada A, Hanada N (2004) Sexual differences in oral health behaviour and factors associated with oral health behaviour in Japanese young adults. Public Health. 118:104-9. [Crossref]

18. Åstrøm AN (2004) Stability of oral health-related behaviour in a Norwegian cohor between the ages of 15 and 23 years. Community Dent Oral Epidemiol. 32:354-62. [Crossref]

19. Kumar S (2012) Oral Hygiene Awareness among Two Non Professional College Students in Chennai, India-A Pilot Study. Oral Hygiene. 5.

20. Al-Hussaini R, Al-Kandari M, Hamadi T, Al-Mutawa A, Honkala S, et al. (2003) Dental health knowledge, attitudes and behaviour among students at the Kuwait University Health Sciences Centre. Med Princ Pract. 12:260-5. [Crossref] 
21. Paulander J, Axelsson P, Lindhe J (2003) Association between level of education and oral health status in 35-, 50-, 65-and 75-year-olds. J Clin Periodontol. 30:697-704. [Crossref]

22. Rimondini L, Zolfanelli B, Bernardi F, Bez C (2001) Self-preventive oral behavior in an Italian university student population. J Clin Periodontol. 28:207-11. [Crossref]

23. KirtiloÄŸlu T, Yavuz US (2006) An assessment of oral self-care in the student population of a Turkish university. Public Health 120: 953-957. [Crossref]
24. Doshi D, Baldava P, Anup N, Sequeira PS (2007) A comparative evaluation of selfreported oral hygiene practices among medical and engineering university students with access to health-promotive dental care. J Contemp Dent Pract. 8:068-75. [Crossref]

25. Taani DQ (2002) Periodontal awareness and knowledge, and pattern of dental attendance among adults in Jordan. Int Dent J. 52:94-8. [Crossref]

26. Tang WK, Sun FC, Ungvari GS, O’Donnell D (2004) Oral health of psychiatric inpatients in Hong Kong. Int J Soc Psychiatry 50: 186-191. [Crossref]

Copyright: $\odot 2017$ Maqsood S. This is an open-access article distributed under the terms of the Creative Commons Attribution License, which permits unrestricted use, distribution, and reproduction in any medium, provided the original author and source are credited. 